\title{
Determination of plant characteristics used in discharge capacity assessment of Turkey Creek watershed on South Carolina coastal plain, USA
}

\author{
DOROTA MIROSŁAW-ŚWIĄTEK ${ }^{1}$, DEVENDRA M. AMATYA ${ }^{2}$ \\ ${ }^{1}$ Department of Hydraulic Engineering, Warsaw University of Life Science - SGGW \\ ${ }^{2}$ Center for Forested Wetlands Research, US Forest Service
}

\begin{abstract}
Determination of plant characteristics used in discharge capacity assessment of Turkey Creek watershed on South Carolina coastal plain, USA. Riparian vegetation type, composition, structure, and its abundance on floodplains exert a strong influence on riparian surface and subsurface hydrology and discharges of rivers and streams. The conditions of flood waters flow in such valley types are shaped by the existing vegetation cover. In this study, on the basis of vegetation inventory in four selected and representative basins, the substitute geometrical parameters of the medium and tall vegetation were determined and friction coefficients for low vegetation. These parameters were determined for $72 \mathrm{~km}^{2}$ forested watershed draining a 3rd order stream as affected by floodplain riparian vegetation on the Atlantic Coastal Plain in South Carolina, USA. The vegetation parameters, determined directly from the measurements, were verified against the rating curve, that was achieved from discharge measurements as well as from discharge capacity calculations of the valley cross-section. In discharge capacity calculation, the Pasche method was used to calculate the total Darcy-Weisbach friction factor for each cross section according to the type of vegetation and flow interaction between the main channel and vegetated areas. In this approach friction caused by interaction between the main channel and vegetated areas are taken into account. The calculations performed on the basis of determined geometrical parameters of tall vegetation, show good agreement between the model and the measurements.
\end{abstract}

Key words: Francis Marion National Forest, Stream flow, Roughness coefficient, Darcy-Weisbach formula, Pasche method.

\section{INTRODUCTION}

Riparian floodplains are among the most biologically diverse and productive ecosystems worldwide, but their ecological integrity is compromised by regulation of flow by dams, reservoirs, and revetments (Whited et al. 2007). The diversity of aquatic and terrestrial floodplain habitats is controlled and maintained by variations within the hydrologic regime that influence habitat distribution and turnover. A primary goal in riparian ecology is to develop general frameworks for prediction of vegetation response to changing environmental conditions including flow standards for rivers and streams (Merritt et al. 2009). At the same time, the vegetation species type, structure, and distribution on the riparian floodplain also influences velocity of flow due to vegetation resistance, for that matter, discharge magnitudes, especially for high flow events when the stage of the water is on floodplain exceeding the bank-full capacity. Flood plain vegetation significantly affects flood extent in the valley, which is a part of self regulatory mechanism in river-floodplain ecosystems relations (Świątek et al. 2008). Many studies were carried out 
in the past to investigate the hydraulic impact of natural roughness such as bank and floodplain vegetation or bed roughness of different textures on the overall flow field (Światek et al. 2008; Wu 2008; Kubrak and Nachlik 2003; Pasche and Rouve 1985). However, discharge rates at various locations along the main stream as well as tributaries of streams are rarely available although they are often needed to evaluate the culvert and bridge discharge capacities, flooding and pollutant loadings from subwatersheds draining lands with various management practices (Amatya and Radecki-Pawlik 2007). Such measurements or estimates are even more important for validating distributed watershed-scale models for their internal consistency as they are generally validated with measurement at the main watershed outlet only (Amatya et al. 2011). Furthermore, these estimates are becoming increasingly important in evaluating the influence of riparian vegetation ecosystem on flow regime characterized by stage, velocity, and discharge at various locations of the rivers and streams.

The main objective of this study is (a) - to determine of hydraulic characteristic of complex riparian floodplain vegetation on Turkey Creek watershed in coastal South Carolina and (b) - to develop a method to estimate in this area flood discharge capacity of a forested stream influenced by this riparian floodplain vegetation.

\section{MATERIALS AND METHODS}

\section{Determination of friction factors}

Hydraulic calculations of the flow in natural rivers with floodplain require methods which include natural vegeta- tion structure of the river waterside zones and the floodplain. The values of the resistance coefficients of the floodplain vegetation still belong to rareness. Presently the most often used are roughness coefficients for Manning's equation, but the choice of the sufficient one among the tabular values is subjective. Another method is determination of plant characteristics elaborated by Pasche and Rouve (1985). The division on high, medium and low vegetation (proposed by Bretschneider and Schulz 1985) is used in such calculations. High vegetation is considered here as higher than water flow depth (trees and shrubs) and in small degree go under hydrodynamic water pressure, medium vegetation as approximately equal to water depth (mostly shrubs) and low vegetation which refers mostly to sedge and grass communities (Fig. 1). Established criterion is ambiguous and in fact the same vegetation can be ranked into different types in view of the natural water levels variability.

The basis of hydraulic calculations of river flow including its natural vegetation structure of high and medium vegetation is assumption that water flow resistances are the same as resistances which occur when water overflow regularly distributed vegetation with averaged geometric parameters (DVWK 1991; Kubrak and Nachlik 2003).

Parameters which describe vegetation of the floodplain and are used in calculations are an average tree diameter or shrubs branches $d_{p}$ and distances between them in the direction of the water flow $a_{x}$ and transversal to it $a_{y}$ (Fig. 2). Named parameters are determined on the basis of field measurements in the area of the water flow. 


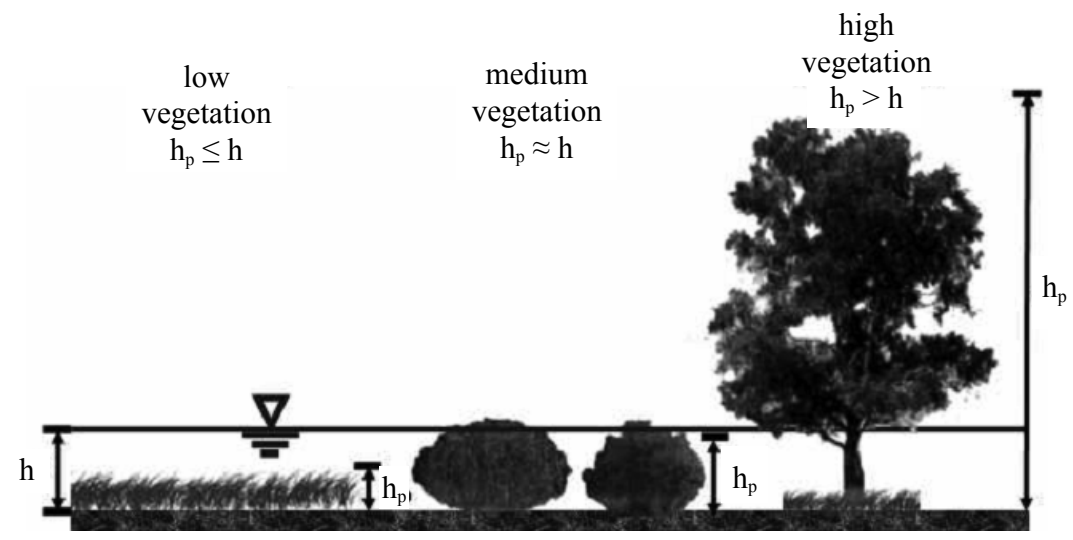

FIGURE 1. Vegetation classification proposed by Bretschneider and Schulz (1985)

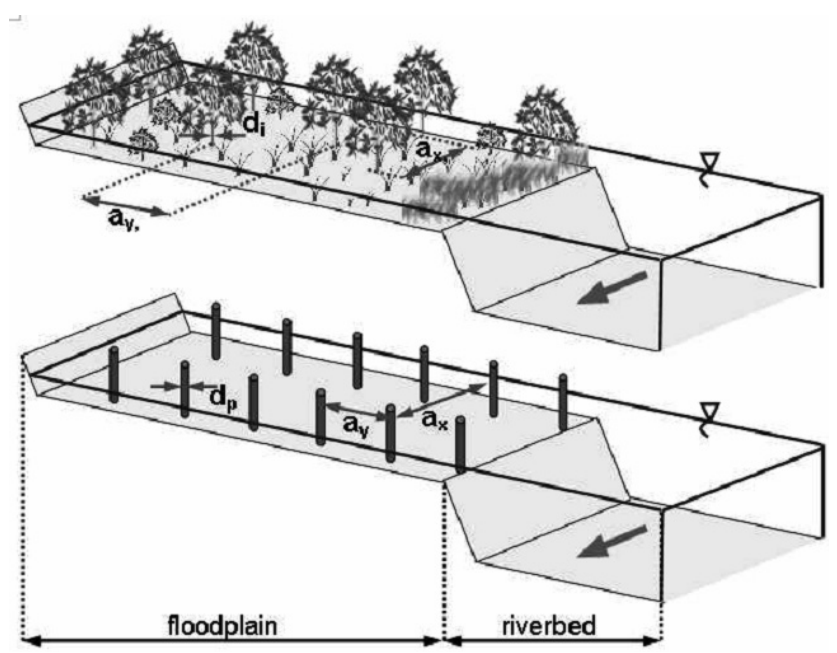

FIGURE 2. The high vegetation geometric characteristics

The resistance of flow caused by the roughness of low vegetation occurring on the scarp, the channel bed and floodplain is calculated from the formula given by Colebrook-White:

$$
\frac{1}{\sqrt{\lambda_{s}}}=2.03 \log \left(\frac{2.51}{\operatorname{Re} \sqrt{\lambda_{s}}}+\frac{k_{s}}{14.84 R}\right)
$$

where: $\begin{aligned} \lambda_{s} & - \text { friction factor of low vegetation or not } \\ & \text { overgrown part of the cross-section }[-] ;\end{aligned}$ $k_{s}$ - roughness height of the overgrown (low vegetation) or not overgrown cross-section $[\mathrm{m}]$;

$R e$ - the Reynolds number for part of the cross-section.

The friction factor $\lambda_{v}$ for trees and bushes (submerged part of high vegetation) is calculated from the following expression (Pasche and Rouve 1985):

$$
\lambda_{v}=\frac{4 h_{z} d_{p}}{a_{x} a_{y}} C_{W R}
$$


where:

$h_{z}$ - height of submerged part of trees [m];

$d_{p}$ - trees diameter [m];

$a_{x}, a_{y}-$ distance between plants along the

flow and transversal;

$C_{W R}$ - dimensionless drag coefficient for submerged part of the trees or bushes.

The drag coefficient $C_{W R}$ depends on the ratio of the $V_{i}$ flowing velocity to the average velocity $V_{v}$ of the flow going through tree overgrown areas, and was described by the empirical formula given by Rickert (1988).

The resistance of flow in parts of cross-sections overgrown by high vegetation depends on both vegetation and bed roughness. The friction factor for this area, according to the concept issued by Einstein and Banks (Indlekofer 1981), is the following sum:

$$
\lambda=\lambda_{s}+\lambda_{v}
$$

where:

$\lambda$ - average friction factor in part of the cross-section [-];

$\lambda_{s}-$ friction factor caused by channel bed roughness or low vegetation [-];

$\lambda_{v}-$ friction factor for non-submerged and non-flexible vegetation (high vegetation) [-].

Physically, composite roughness along the wetted perimeter of the compound cross section modifies velocity distribution in the cross section. A detailed examination of the effects of varying wall roughness and cross sectional geometry would require a three-dimensional analysis of the flow. Pasche and Rouve (1985) proposed one-dimensional analysis of steady flow in a compound cross-section of the lowland river based on the Darcy-Weisbach formula. According to the observed velocity distribution a compound river cross section is divided into sections with vertical imaginary walls with roughness height of channel $k_{T}$ and friction factor $\lambda_{T}$ between the main channel and neighboring floodplains (Fig. 3). The heights of these boundaries $\left(h_{T 1}, h_{T 2}\right)$ are taken into consideration in calculations of the wetted perimeter of the main channel. Mean velocity in each section (in Fig. 3. signed by symbols $T_{1}$ and $T_{2}$ for vertical imaginary walls and numbers 1, 3, 2 for scarps and channel bed) for a channel is calculated from the Darcy-Weisbach equation, which results from the momentum balance in part ' $i$ ' of the cross-section:

$$
v_{i}=\sqrt{\frac{8 g R_{i} S_{f}}{\lambda_{i}}}
$$

where:

$S_{f}$ - hydraulic slope [-];

$v_{i}$ - average velocity in the ' $i$ 't ' sub-domain of the main channel;

$\lambda_{i}$ - friction factor of the ' $i^{t \text { th }}$ sub-domain.

The average friction factor in the whole main channel $\lambda_{g}$ is calculated with consideration of the friction factors in every sub-section of the main channel (Fig. 3):

$$
\lambda_{g}=\frac{\lambda_{T 1} h_{T 1}+\sum_{i=1}^{3} \lambda_{i} w p_{i}+\lambda_{T 2} h_{T 2}}{h_{T 1}+\sum_{i=1}^{3} w p_{i}+h_{T 2}}
$$

The friction factor $\lambda_{i}$ is calculated from the formula (5), in which hydraulic radius $R_{i}$ and $R_{T 1}, R_{T 2}$ related to different roughness factors in cross-sections is determined according to the concept by Einstein (Kubrak and Nachlik 2003), assuming the equality of average velocity (4) in the main channel $v$ and average velocity $v_{i}$ in the every sub-domain $i$ : 


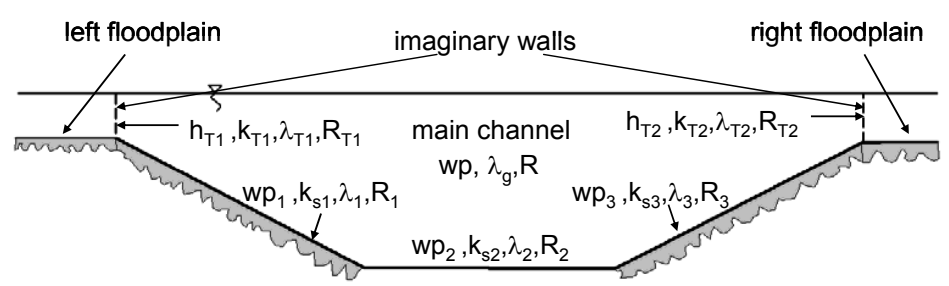

FIGURE 3. Schema of main channel sub-sections with different hydraulic parameters

$$
\sqrt{\frac{8 g R_{i} S_{f}}{\lambda_{i}}}=\sqrt{\frac{8 g R S_{f}}{\lambda_{g}}}
$$

When floodplain is covered by low vegetation, the interface of the floodplain from the main channel is treated as the rough wall with roughness height $k_{T 1}, k_{T 2}$, that have the same values like left and right scarp of the main channel. The calculation of the hydraulic radius for different roughness factors in cross-sections is conducted using the iterative method.

The way of calculation of flow intensity in the floodplain with trees is more sophisticated and based on the theory proposed by Pasche and Rouve (1985). According to the observed velocity distribution the compound channel is divided into four sections. Due to the horizontal mass and momentum exchange between areas with steep velocity gradients the flow is reduced in the main channel and accelerated on the floodplain. At calculation of the discharge in the main channel, the interface plane of the floodplain from the main channel is treated as the rough wall with roughness of channel $k_{T}$ and friction factor $\lambda_{T}$. The friction coefficient $\lambda_{T}$ in interface plane is introduced to determine the flow reduction in the main channel, while the discharge on the floodplain is increased. The roughness height in the interfaces is calculated from the formulas given by Pasche (1985) (Kubrak and Nachlik 2003).

\section{High vegetation}

Characteristics of a dense tree or bush group

Floodplains and riparian zones of rivers are usually covered by groups of trees or bushes. The inventory of those tree or bush groups is carried out on elementary, rectangular - like areas $A_{\text {pro }}$ which are 10 by $20 \mathrm{~m}$ in size. The surface of elementary, inventory area shouldn't exceed several square meters (DVWK 1991; Kozioł et al. 2002). On the basis of the performed inventory of tree and bush groups, the substitute diameter of trees or bush branches is calculated and mean distances between plants are estimated. The substitute diameter is the mean value of the diameters measured at the water level elevation:

$$
d_{p}=\frac{\sum d_{i}}{n}
$$

where:

$d_{p}$ - substitute diameter of trees/bushes,

$d_{i}$ - diameter of a tree/bush,

$n$ - number of trees or bush branches on the inventory area.

The substitute distance between trees or branches in the direction of water flow $-a_{x}$ and transverse to it $-a_{y}$, when these 
distances are equal $\left(a_{x}=a_{y}\right)$, is calculated form the following formula:

$$
a_{x}=a_{y}=\sqrt{\frac{A_{\text {pro }}}{n}}
$$

When these distances are not equal, basing on the results of measurements, the surface occupied by one plant is calculated $a_{x} \cdot a_{y}=A_{p r o} / n$, next, the mean value of the distance ratio is calculated: $a_{y} / a_{x}=C$ and by substitution $a_{y}=C \cdot a_{x}$, the distance $a_{x}=\left[A_{p r o} /(n \cdot C)\right]^{0.5}$ is achieved.

Characteristics of single bushes and trees on floodplains

The value of mean surface occupied by a tree or a bush is calculated as a result of measurements of a surface $A_{P R, i}$ which is occupied by $\mathrm{i}$-th tree or bush:

$$
A_{P R}=\frac{\sum A_{P R, i}}{n}
$$

where:

$A_{P R, i}$ - is the surface of i-th tree cross-section, $n \quad-$ is the number of trees or bush branches.

The substitute diameter of a tree or a bush branch $d_{p}$ is calculated on the basis of the mean cross-sectional area:

$$
d_{p}=\sqrt{\frac{4 A_{P R}}{\pi}}
$$

The substitute diameter between plants in the direction of water flow $-a_{x}$ and transverse to it $a_{y}-$ is determined as previously described.

Characteristics of mixed tree and bush groups

In the case of mixed groups of trees and bushes it is recommended to determine substitute parameters for both plant groups altogether.

Initial inventory of plants on an analysed area is executed, and next the substitute diameter is calculated from the following formula:

$$
d_{p}=\frac{d_{k} \cdot n_{k}+d_{d} \cdot n_{d}}{n_{k}+n_{d}}
$$

where:

$n_{k}$ - number of bush branches,

$n_{d}$ - number of trees,

$d_{k}$ - bush branch diameter,

$d_{d}$ - diameter of trees.

Substitute distances between plants are calculated as given in previous examples.

\section{STUDY AREA}

The Turkey Creek watershed is a 3rd order stream system draining an approximate area of 7.260 ha. It is located at $33^{\circ}$ $08^{\prime} \mathrm{N}$ latitude and $79^{\circ} 47^{\prime} \mathrm{W}$ longitude approximately $60 \mathrm{~km}$ north-west of City of Charleston near Huger, in Berkeley County of South Carolina (Fig. 4). It is the headwaters of East Cooper River, a major tributary of the Cooper River, which drains to the Charleston Harbor. Turkey Creek (WS 78) is typical of other watersheds in the south Atlantic coastal plain where rapid urban development is taking place. The topographic elevation of the watershed varies from $3.6 \mathrm{~m}$ at the outlet to $14 \mathrm{~m}$ above mean sea level (amsl). The sub-tropical climate is characteristic of the coastal plain having hot and humid summers and moderate winters. Accordingly, the minimum and maximum air temperatures, based on a 50-year (1951-2000) record at the Santee Experimental Forest, were recorded as 


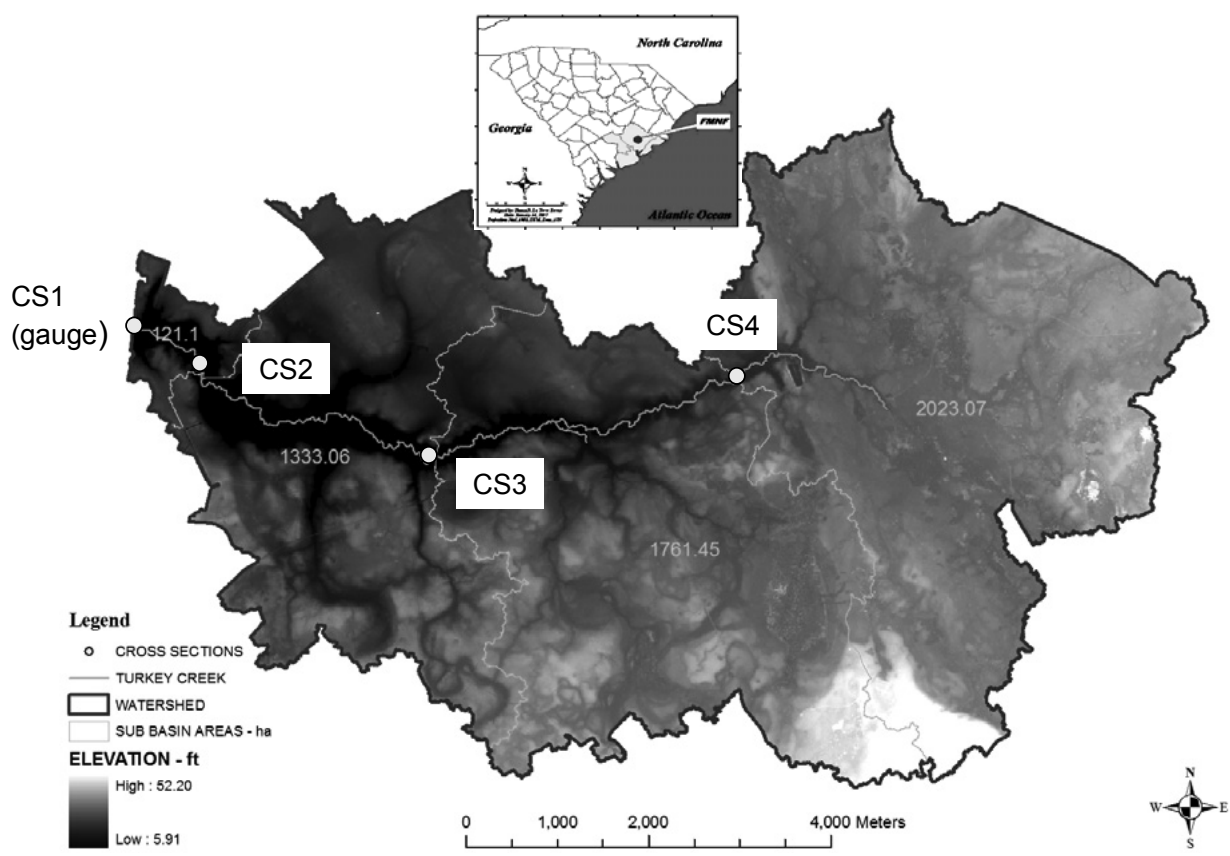

FIGURE 4. Location of the Turkey Creek watershed on Francis Marion National Forest in South Carolina lower coastal plain

$-8.5^{\circ} \mathrm{C}$ and $37.7^{\circ} \mathrm{C}$, respectively, with an average daily temperature of $18.4^{\circ} \mathrm{C}$. Annual rainfall at the site varied from $830 \mathrm{~mm}$ to $1940 \mathrm{~mm}$, with an average of $1370 \mathrm{~mm}$ based on the 50-year (1951-2000) data. Seasonally, the winter is generally wet with low intensity long duration rain events and the summer is characterized by short duration, high intensity storm events; tropical depression storms are not uncommon.

Hydrography of the Turkey Creek watershed is characterized by a $9.75 \mathrm{~km}$ long main channel and its network of narrow tributaries with wide floodplains. The right bank, or north bank, of Turkey Creek has shorter and fewer tributaries compared to the left bank. Many of the tributaries are ephemeral and intermittent, including certain upper reaches of the main creek. Most channels within Turkey Creek watershed are larger in width compared to depth. The main channel is $10 \mathrm{~m}$ or even more towards downstream, often with wide flood plains and islands in the winding parts of the creek (Haley 2007; Amatya et al. 2009) (Fig.5).

Land use within the watershed is comprised of $88 \%$ pine forest (mostly regenerated loblolly (Pinus taeda) and long leaf pine (Pinus palustris), 10\% wetlands and water, and $2 \%$ agricultural lands, roads and open areas (Haley 2007). Over $50 \%$ of the forest is comprised of Bald Cypress, Water Tupelo, and Loblolly Pine The watershed was heavily impacted by Hurricane Hugo in September, 1989, and the forest overstory trees were almost completely destroyed (Hook et al. 1991). The current forests 


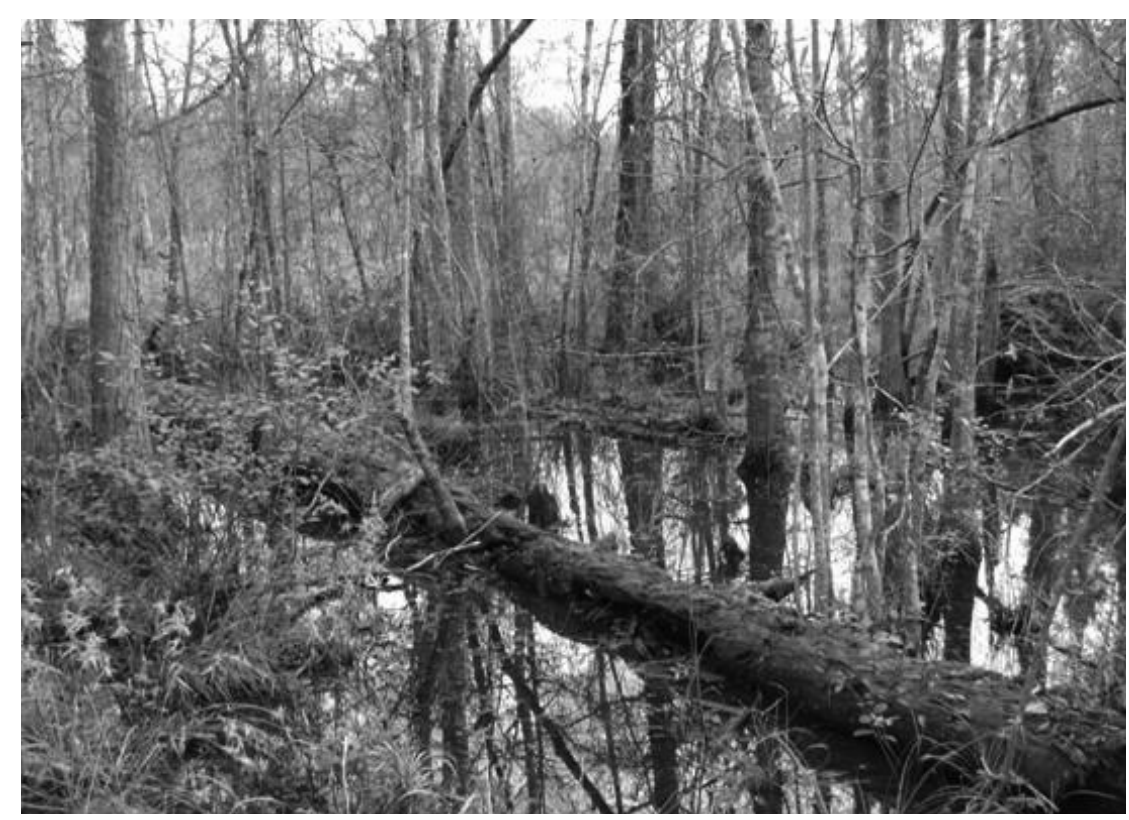

FIGURE 5. Photograph of Turkey Creek stream showing dense vegetation and woody debris on its floodplain

on the watershed are a mixture of remnant large trees and natural regeneration. The forests are managed using prescribed fire and thinning for restoration of those native forest species also for supporting habitat requirements for the endangered red cockaded wood peckers (Pinoides borealis) (La Torre Torres et al. 2010). The stand activities on the watershed for 2005 to 2008 period were as follows: 2005: no thinning or harvesting, 2006: 151.1 ha (373.3 ac) cut, 2007: $31.3 \mathrm{ha}(77.4 \mathrm{ac})$ cut, and 2008: $48.6 \mathrm{ha}$ $(120 \mathrm{ac})$ cut. These numbers show that the largest area of 151.1 ha cut in 2006 was only $2.1 \%$ of the whole watershed area $(7.260 \mathrm{ha})$. The vegetation on the riparian floodplain of the Turkey Creek stream is a mixed forest comprising mostly of bottomland hardwood including cypress and some pine.

\section{Hydrologic monitoring}

Streamflow

Stream flow is obtained from real time stage measurements at 15-minute intervals using a Sutron data logger connected to a pressure transducer anchored on the stream bottom (Amatya and Trettin, 2007) at the gauging station which is located at the outlet of the watershed near the bridge on Hwy 41 (Fig. 4). There are not any other flow monitoring stations upstream in the main channel for validating the results calculated by the method developed herein and formulated below.

\section{ASSESSMENT OF GEOMETRIC PLANT CHARACTERISTICS}

In order to determine characteristic parameters of the vegetation of Turkey Creek watershed, the inventory of the 
vegetation, existing in the water flow zone, was performed at four cross-sections, containing vegetation communities typical for that area (Fig. 5).

At all cross-sections (four), there were similar species of trees and steams, forming tall vegetation, and low vegetation that is included into the understroy. Table 1 contains the vegetation, that was identified at the analysed cross-sections. At the cross-section CS-4, that was located in the upstream part of the watershed, there were also the bushes such as: Fether Bush, Wax Myrtle, Switchgrass, which were identified as tall vegetation The height of the bottom vegetatation was larger than at other three cross-sections.

The performed inventory enabled to estimate the geometrical parameters of tall vegetation and roughness coefficient for the plants included into the understroy.

The calculations of the substitute diameter of the plants were performed

TABLE 1. Vegetation type in the Turkey Creek watershed

\begin{tabular}{|l|l|}
\hline \multicolumn{1}{|c|}{ Trees } & \multicolumn{1}{c|}{ Understroy } \\
\hline Amerikan Holly & Grass \\
\hline Red Maple & Trumpet Creeper \\
\hline Iron Wood & Elliot \\
\hline Water Oak & Blueberry \\
\hline Black Gum & Trumpet \\
\hline Swamp Chestnut Oak & Creeper \\
\hline Arrow Wood & Seedling \\
\hline Sweet Gum & Poison Ivy \\
\hline Laurel Oak & Smilax \\
\hline Carolina Ash & Alabama Suppjack \\
\hline Loblolly Pine & Honeysuckle \\
\hline Red Mulberry & Switchcanc \\
\hline American Elm & Parteridge Berry \\
\hline Cypress & Chain Fern \\
\hline
\end{tabular}

with the use of formula (11), while the mean diameters in formula 11 for steams and trees were calculated from formula (7). The steams, present at cross-section CS-4 were treated as single steams, so formulas (9) and (10) were used to determine their substitute diameters. Table 2 contains the calculated geometrical characteristics of tall vegetation and the estimated absolute roughness coefficients of the understroy for all analysed, four cross-sections. It can be seen, that the mean substitute diameters for cross-sections CS- 1 and CS-3 range from 0.06 to $0.09 \mathrm{~m}$ and these differences are insignificant. Maximum difference does not exceed $0.03 \mathrm{~m}$. Mean distances between plants are very similar for cross-sections CS-1, CS-3 i CS-4 and their variability range is from 1.21 to $1.31 \mathrm{~m}$. More dense tall plant setting is present at cross-section CS-2 $\left(\mathrm{a}_{\mathrm{x}}=\mathrm{a}_{\mathrm{y}}=1.05 \mathrm{~m}\right)$. The roughness height for low vegetation, that forms the understroy at cross-sections, CS-1 - CS-3 was estimated to be $0.3 \mathrm{~m}$. At the cross-section, located in the upstream part of the watershed, the height of the understroy is higher, and $k_{s}$ is estimated to be $0.4 \mathrm{~m}$. The determination of $k_{s}$ values was based on measurements of understoy vegetation at the analyzed cross-sections and on the values given in Ritterbach (1991).

The vegatation cover of the main channel at CS-4 cross-section differs considerably form three other cross-sections. This is because of the presence of Cypres Knee communities (Fig. 6), which are characteristic for forested floodplain on the Atlantic Coastal Plain in South Carolina.

The Cypres knee, existing in the main river channel, on account of its compara- 
TABLE 2. Geometric plant characteristic and roughness height estimated for the Turkey Creek watershed

\begin{tabular}{|c|c|c|c|c|c|c|c|c|c|c|}
\hline $\begin{array}{c}\text { Cross- } \\
- \text { Section } \\
\text { Name }\end{array}$ & $\begin{array}{c}\text { Drainage } \\
\text { Area } \\
{\left[\mathrm{km}^{2}\right]}\end{array}$ & $\begin{array}{c}\mathrm{A}_{\text {pro }} \\
{\left[\mathrm{m}^{2}\right]}\end{array}$ & $\begin{array}{c}\mathrm{n}_{\text {tree }} \\
\mathrm{n}_{\text {bush }}\end{array}$ & $\begin{array}{c}\mathrm{d}_{\text {tree }} \\
\mathrm{d}_{\text {bush }} \\
{[\mathrm{m}]}\end{array}$ & $\mathrm{n}_{\text {stem }}$ & $\begin{array}{c}\mathrm{d}_{\text {stem }} \\
{[\mathrm{m}]}\end{array}$ & $\begin{array}{c}\mathrm{d}_{\text {aver }} \\
{[\mathrm{m}]}\end{array}$ & $\begin{array}{c}\mathrm{a}_{\mathrm{x}} \\
{[\mathrm{m}]}\end{array}$ & $\begin{array}{c}\mathrm{a}_{\mathrm{y}} \\
{[\mathrm{m}]}\end{array}$ & $\begin{array}{c}\mathrm{k}_{\mathrm{s}} \\
{[\mathrm{m}]}\end{array}$ \\
\hline $\mathrm{SC}-1$ & 65.09 & $12 \times 15=180$ & 24 & 0.24 & 81 & 0.035 & 0.072 & 1.31 & 1.31 & 0.3 \\
\hline $\mathrm{SC}-2$ & 64.36 & $17 \times 15=255$ & 74 & 0.13 & 157 & 0.031 & 0.060 & 1.05 & 1.05 & 0.3 \\
\hline $\mathrm{SC}-3$ & 55.56 & $15 \times 15=225$ & 94 & 0.12 & 43 & 0.037 & 0.090 & 1.38 & 1.38 & 0.3 \\
\hline $\mathrm{SC}-4$ & 31.67 & $15 \times 17=255$ & $\begin{array}{c}58 \\
25\end{array}$ & $\begin{array}{c}0.16 \\
0.50\end{array}$ & 91 & 0.031 & 0.140 & 1.21 & 1.21 & 0.4 \\
\hline
\end{tabular}
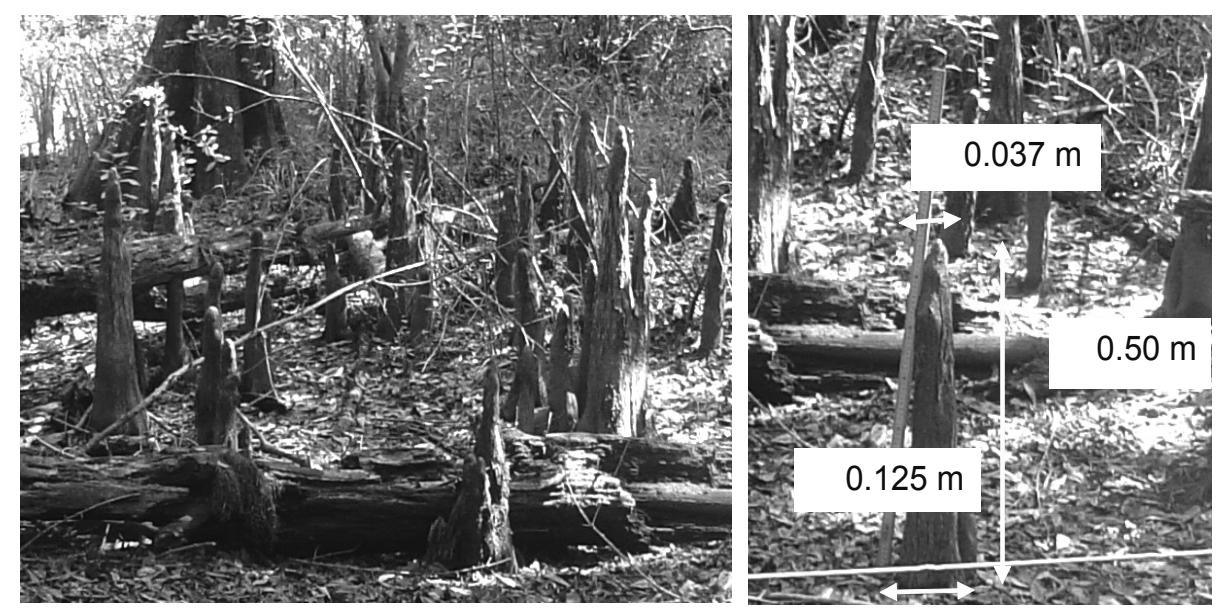

FIGURE 6. Cypres knee in main channel at CS-4

TABLE 3. Geometric Cypres Knee characteristic and roughness height estimated for the main channel at cross-section CS-4

\begin{tabular}{|c|c|c|c|c|c|}
\hline $\begin{array}{c}\mathrm{A}_{\text {pro }} \\
{\left[\mathrm{m}^{2}\right]}\end{array}$ & $\mathrm{n}_{\text {tree }}$ & $\begin{array}{c}\mathrm{d}_{\text {tree }} \\
{[\mathrm{m}]}\end{array}$ & $\begin{array}{c}\mathrm{a}_{\mathrm{x}} \\
{[\mathrm{m}]}\end{array}$ & $\begin{array}{c}\mathrm{a}_{\mathrm{y}} \\
{[\mathrm{m}]}\end{array}$ & $\begin{array}{c}\mathrm{k}_{\mathrm{s}} \\
{[\mathrm{m}]}\end{array}$ \\
\hline $3.7 \times 4=14.8$ & 32 & 0.08 & 0.68 & 0.68 & 0.1 \\
\hline
\end{tabular}

ble height to the water depth, were treated in the calculations as tall vegetation, for which mean geometrical parameters were presented in Table 3. It was estimated, that the bed roughness at the main channel totals $0.10 \mathrm{~m}$ for that cross-section.

\section{DISCHARGE CAPACITY CALCULATION}

The previously determined characteristics of various vegetation types were then used to calculate resistance coefficients for the plants. These calculations were performed for the gauged cross-section CS-1 (Fig. 4). Figure 7 presents the geometry of that cross-section, elaborated by USGS basing on bathymetric measurements of the river bed and geodetic measurements on the floodplains. The selection of that cross-section made possible to compare the rating curve, estimated 


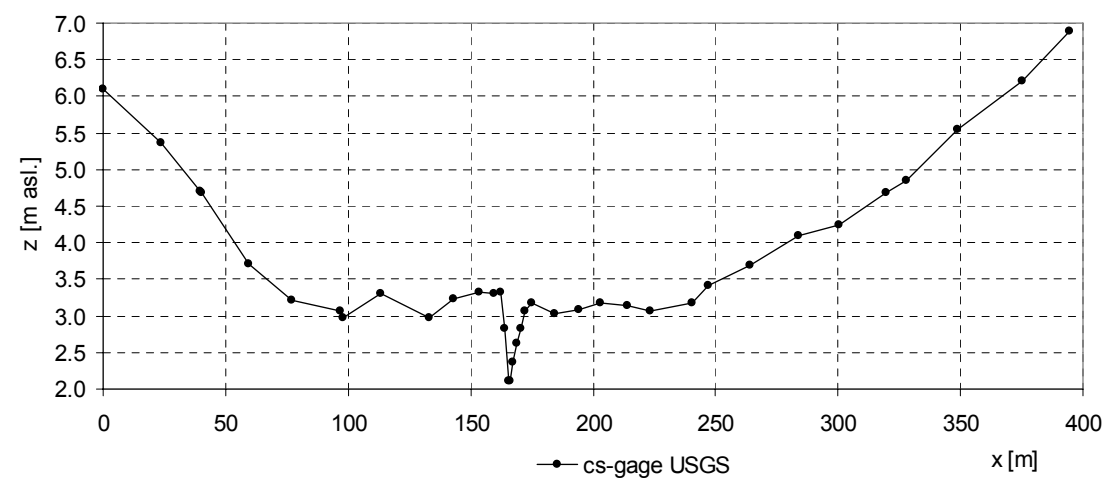

FIGURE 7. Geometry of the main channel and river valley for gauge transect selected for capacity calculations

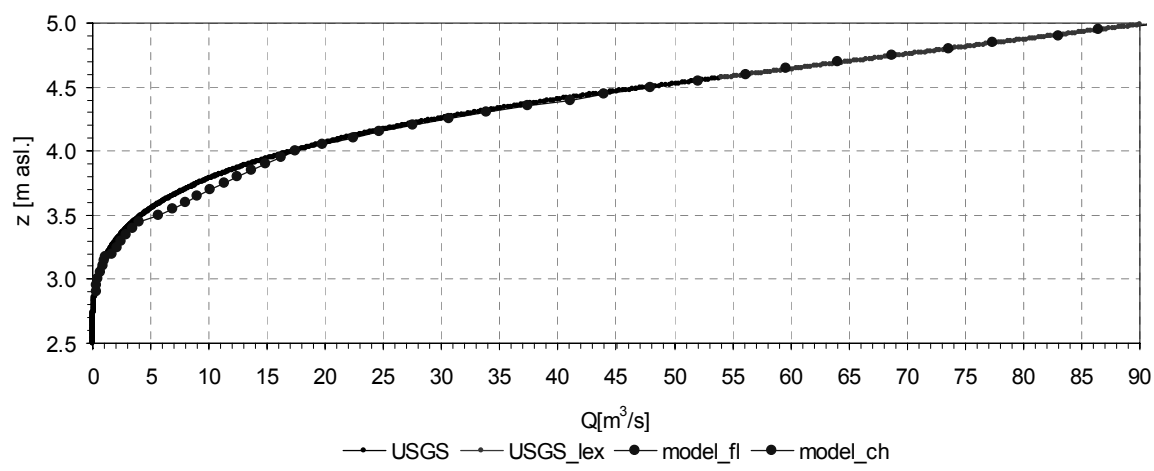

FIGURE 8. Rating curve calculated by discharge capacity calculation with influence high vegetation and developed by USGS (USGS-lex - linear extrapolated values, model_fl - floodplain area, model - ch - main channel area)

from the calculations of the riverbed capacity from formulas $1-6$, with the rating curve elaborated by USGS (2000) discharge measurements. By applying the linear extrapolation, the rating curve was extended until the water level elevation on the floodplain equal to $5 \mathrm{~m}$ a.s.l. (Amatya et al. 2008). The value of the absolute roughness height for the main river channel was achieved by minimizing the differences between the modeled discharges and the discharges estimated from the rating curve, calculated by the model for water levels below bankful water. The best match was obtained for $k_{s}=0.24 \mathrm{~m}$. for which the mean square error was equal to $0.04 \mathrm{~m}^{3} / \mathrm{s}$ and Nash-Sutcliffe (NS) efficiency reached 0.994. These achieved values prove a very good model representation of flows in the range of bankful water.

The discharges, calculated for the water levels higher than the bankful water, also prove a very good agreement with discharges estimated from the rating curve (Fig. 8). In this case the mean square error totals $1.17 \mathrm{~m}^{3} / \mathrm{s}$ while Nash-Sutcliffe (NS) efficiency is equal to 0.98 . 
Good match of the modeled and the observed discharges gives evidence for proper estimation of tall and low vegetation geometrical parameters at that cross section. Because the structure of the vegetation does not differ much at other cross-sections, it can be assumed, that the estimated parameters can be used for calculations of discharge capacity at that area.

Figure 9 presents the resistance coefficients $\lambda$ calculated for the main channel as well as for the right and the left floodplain. On the right floodplain they reach silghtly higher values at the same water level, which is caused by the difference in geometry of the computational crosssection. With the increase of the water depth of the main channel, the resistance coefficient decreases from 0.115 for low water stages to 0.07 for high water stages. Analysing the Figure 9, it can be concluded, that at low water stages at floodplains the resistance coefficient $\lambda$ decreases at first, and then it increases with the increase of water depth. It can be explained by the motion resistance of high vegetation being lower at low water levels, than the resistance of low vegetation, that decrease with increasing water depth. At higher water levels on floodplains, the resistance coefficient $\lambda_{v}$ related with tall vegetation grows intensively, and $\lambda_{s}$ decreases. The resistance coefficients of the vegetated floodplain are several times higher than those coefficients determined for the main river channel.

\section{Acknowledgement}

Authors wishes to acknowledge the financial support offered by OECD fellowship and U.S. Fulbright Fellow.

\section{REFERENCES}

AMATYA D.M., JHA M., EDWARDS A.E., WILLIAMS T.M., HITCHCOCK D.R. 2011: SWAT-based streamflow and embayment modeling of karst affected Chapel Branch watershed, SC. In revision, Trans. of the ASABE.

AMATYA D.M., CALLAHAN T.J., TRETTIN C.C., RADECKI-PAWLIK A. 2009: Hydrologic and Water Quality Monitoring on Turkey Creek Watershed, Francis Marion National Forest, SC. ASABE paper \# 09-5999, prepared for presentation at the June 21-24, Annual ASABE Int'l Meeting, Reno, NV, 21 .

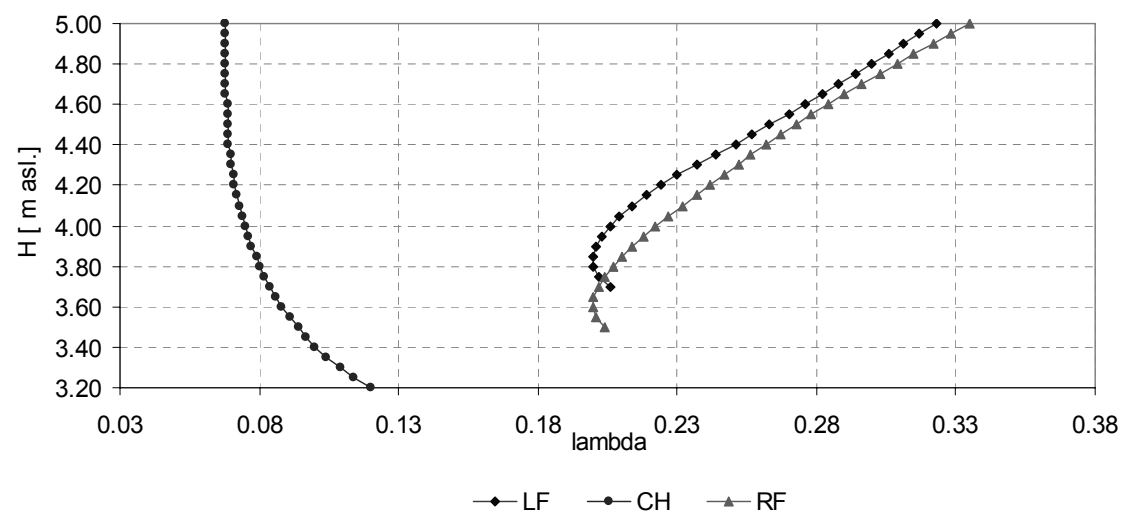

FIGURE 9. Friction factors $(\lambda)$ variability in the main channel $(\mathrm{CH})$ and left $(\mathrm{LF})$ and right $(\mathrm{RF})$ floodplain, calculated at gauge cross-cection CS-1 
AMATYA D.M., HALEY E.B., LEVINE N.S., CALLAHAN T.J., RADECKI-PAWLIK A., JHA M. 2008: Calibration and Validation of the SWAT Model for a Forested Watershed in Coastal South Carolina. ASABE Paper \# 08-3912, 2950 Niles Rd., St. Joseph, MI: ASABE.

AMATYA D.M., RADECKI-PAWLIK A. 2007: Flow Dynamics of Three Experimental Forested Watersheds in Coastal South Carolina, U.S.A. Acta Scientiarium Polonorum Formatio Cirtumiectus, no 1, 2007.

AMATYA D.M., TRETTIN C.C. 2007: An Ecohydrological Project on Turkey Creek Watershed, South Carolina, U.S.A. In P. Meire et al. (eds.) "Integrated Water Management: Practical Experiences and Case Studies", NATO Science Series IV: Earth and Environmental Sciences, Springer, Netherlands, p. 115-126.

BRETSCHNEIDER H., SCHULZ A. 1985: Anwendung von Fließformeln bei naturnahem Gewässerausbau. DVWK - Schriften, Heft 72.

DVWK - MERKBLÄTTER 220, 1991: Hydraulische Berechnung von Fließgewässern, DK 551.51/54 Fließgewässer, DK 532.543 Hydraulik, DVWK - Merkblätter 220/1991, Kommissionsvertrieb Verlag Paul Parey, Hamburg und Berlin.

HALEY E.B. 2007: Field Measurements and Hydrologic Modeling of the Turkey Creek Watershed, South Carolina. MS thesis. Charleston, South Carolina: College of Charleston, p. 168.

HOOK D.D., BUFORD M.A., WILLIAMS T.M. 1991: Impact of Hurricane Hugo on the South Carolina Coastal Pine Forest. J. of Coastal Research, SI (8): 291-300.

INDLEKOFER H. 1981: Überlagerung von Rauhigkeitseinflüssen beim Abfluß in offenen Gerinnen. Mitt. Institut für Wasserbau und Wasserwirtschaft, RWTH Aachen, Heft 37, p. 105-145.

KOZIOE A., KUBRAK J., CIEPIELOWSKI A. 2002: Hydrauliczny model przepustowości koryt rzecznych w warunkach występowania roślinności leśnej. Czasopismo Techniczne Inżynieria Środowiska, Zeszyt 4, Wydawnictwo Politechniki Krakowskiej.

KUBRAK J., NACHLIK E. (red.) 2003: Hydrauliczne podstawy obliczania przepustowości koryt rzecznych. Wydawnictwo SGGW, s. 317.

LA TORRE TORRES I.B., AMATYA D.M., SUN G., CALLAHAN T.J. 2010: Seasonal rainfall-runoff relationships in a lowland forested watershed in the southeastern USA. In press: Hydrol. Proc. 24, (0-0) 2010.

MERRITT D.M., SCOTT M.L., POFF N.L., AUBLE G.T., LYTLE D.A. 2009: Theory, methods and tools for determining environmental flows for riparian vegetation: riparian vegetation-flow response guilds. Freshwater Biology (2009): 1-20.

PASCHE E., ROUVE G. 1985: Overbank flow with vegetatively Roughened flood plains. Journal of Hydraulic Engineering 111(9), 1262-1278.

RICKERT K. 1988: Hydraulische Berechnung naturnaher Gewässer mit Bewuchs. DVWK-Fortbildung, H. 13.

RITTERBACH E. 1991: Wechselwirkungen zwischen Auenökologie und Fließgewässerhydraulik und Möglichkeiten der integrierenden computergestützten Planung. Mitteilungen für Wasserbau und Wasserwirtschaft, Rheinish Westfälische Technische Hochschule Aachen.

ŚWIĄTEK D., SZPORAK S., CHORMAŃSKI J., OKRUSZKO T. 2008: Hydrodynamic Model of the Lower Biebrza River Flow - A Tool for assessing the hydrologic vulnerability of a floodplain to management practices. Ecohydro. \& HydroBio, 8 (2-4), 331-337.

USGS (United States Geological Survey) 2000: The National Flood Frequency Program methods for estimating flood magnitude and frequency in rural and urban areas in South Carolina. US Department of Interior, USGS Fact Sheet 001-00, January 2000.

WHITED D.C., LORANG M.S., HARNER M.J., HAUER F.R., KIMBALL J.S., STANFORD J.A. 2007: Climate, Hydrologic Disturbance, and Succession: Drivers of Floodplain Pattern. Ecology, 88(4), 2007, pp: 940-953.

WU F. 2008: Characteristics of flow resistance in open channels with non-Submerged rigid vegetation. Journal of Hydrodynamics, 2092):239-245 .

Streszczenie: Określenie charakterystyk roślin wykorzystywanych w obliczeniach przepustowości terenów zalewowych rzeki Turkey w Poludniowej Karolinie (USA). Roślinność występująca na terenach zalewowych dolin rzecznych w istotny sposób wpływa na warunki hydrologiczne oraz determinuje warunki przepływu występujące w trakcie wezbrań, kiedy woda występuje z koryta rzeki i płynie w terenach zalewowych. $Z$ drugiej strony 
charakterystyki hydrologiczne zalewów takie jak głębokość wody na zalewie, częstość występowania i czas trwania zalewu, kształtują czynniki siedliskowe związane $\mathrm{z}$ występowaniem danego typu roślinności. W artykule wyznaczono charakterystyki geometryczne związane z oporami przepływu roślinności wysokiej występującej na obszarach zalewowych rzeki Turkey, której zlewnia o powierzchni $78 \mathrm{~km}^{2}$ położona jest w Południowej Karolinie (USA). Współczynniki oporów roślinności wysokiej (krzewy i drzewa) są w głównej mierze uzależnione od oporów opływanej bryły roślin, i obliczane są na podstawie zastępczej przeciętnej średnicy roślin oraz uśrednionych odległościach między nimi w kierunku przepływu i poprzecznym do niego. Charakterystyki te zostały wyznaczone w wyniku inwentaryzacji roślinności w czterech przekrojach pomiarowych, reprezentatywnych dla tego obszaru. W przekroju wodowskazowym wykonano obliczenia przepustowości koryta i terenów zalewowych na podstawie metody Pasche i uniwersalnego prawa przepływu Darcy-Weisbacha. Uzyskane wyniki są zgodne z krzywą przepływu dla tego przekroju opracowaną na podstawie pomiarów.

\section{MS. received 30 November 2011}

\section{Authors' addresses}

Dorota Mirosław-Świątek

Katedra Inżynierii Wodnej i Rekultywacji

Środowiska

Szkoła Główna Gospodarstwa Wiejskiego

ul. Nowoursynowska 159

02-786 Warszawa

Poland

Devendra M. Amatya

Center for Forested Wetlands Research

US Forest Service, Cordesville, SC 29434 